\title{
NÉPSZÁMLÁlÁSI ADATÁlLOMÁNYOK HASZNOSÍTHATÓSÁGA A TÁRSADALMI TAGOLÓDÁS ÉS EGYENLŐTLENSÉGEK KUTATÁSÁBAN
}

\author{
HARCSA ISTVÁN
}

(Reflexiók Nagy Péter Tibor „Az iskolázottsági egyenlőtlenségek és a 18 év alatti népesség a 2011-2016-os időszakban” címmel megjelent írására) ${ }^{1}$ tapasztalatok azt mutatják, hogy a jelenkori társadalom tagolódásával, ${ }^{2}$ valamint ezzel összefüggésben az egyenlőtlenségek alakulásával kapcsolatos kutatások körében meglehetősen ritka a teljes körű statisztikai adatállományok, azon belül is a népszámlálások szociológiai célú felhasználása. Ám - bizonyos kivételtől eltekintve - hasonló a helyzet az adminisztratív adatállományok hasznosítása esetében is (Harcsa 2018). Miért fontos ezt kiemelni? Elsősorban azért, mert a pusztán kismintás felvételekre alapozott kutatások - az alacsony elemszám miatt - komoly korlátot jelentenek számos fontos részlet, és ezzel összefüggő oksági kapcsolat feltárásában. E „módszertani fehérfolt” világában üdítő tanulmányként olvashatjuk Nagy Péter Tibor tanulmányát, aki - viszonylag ritka kivételként - vette a fáradságot, és elkezdte a legutóbbi népszámlálások, valamint a 2016. évi mikrocenzus adatállományainak másodlagos feldolgozását, a KSH kutatószobájában. Írásának a címe ugyan csak az iskolai egyenlőtlenségek bemutatására utal, azonban a tanulmány első fele kizárólag arról szól, hogy - a társadalmi tagoltságot, illetve egyenlőtlenségeket tekintve - milyen lehetőségeket kínálnak az említett adatállományok.

Hangsúlyozni szeretnénk, hogy a szerzőt - korábban és most is - legalább annyira érdekli a statisztikai adatbázisok kutatási célú hasznosíthatósága, mint az iskolázottsági egyenlőtlenségek alakulása. Jelen írása mindkét vonatkozásban figyelmet keltő,

Az írás a Fényes Elek Társadalomstatisztikai Egyesület (FETE) és a BCE SzTI Társadalomstatisztikai Kutatóközpont (TKK) által szervezett műhelyvitára készült, amely Nagy Péter Tibor Az iskolázottsági egyenlötlenségek és a 18 év alatti népesség a 2011-2016-os idöszakban címmel, az Educatio folyóiratban megjelent tanulmányát tárgyalta.

2 A társadalmi tagolódást a sokdimenziós társadalmi térben való elhelyezkedésként értelmezzük, következésképpen viszonylag tág az a tartomány, amelyben a tagoltságot megfigyelhetjük. Ennek megfelelően az osztályok és rétegek szerinti tagolódás mellett ideértjük a különböző társadalmi-demográfiai csoportosításokat, így többek között a demográfiai életúttól, családszerkezettől kezdve a jövedelmi, iskolai végzettség szerinti tagolódáson keresztül egészen a térségi fejlettség szerinti tagoltságig. 
bár nézetem szerint az első cél különösen fontos, hiszen a népszámlálások és a 2016. évi mikrocenzus hasznosíthatóságát igen demonstratív módon mutatja be az érdeklődő kutatók számára. Sőt, úgy vélem, hogy az írás módszertani része kiváló „apropót” adhat annak a korábbi években megfogalmazott elképzelésnek ${ }^{3}$ a felkarolásához, mely szerint a hallgatók és doktoranduszok képzési lehetőségeinek a bővítése érdekében, intézményes kereteket lehetne kialakítani a statisztikai adatállományok kutatási célú hasznosításával. ${ }^{4}$ Itt említjük meg, hogy a Fényes Elek Társadalomstatisztikai Egyesület (FETE) - más kutatói közösségek bevonásával - többször is napirendre tűzte a statisztikai adatállományok, ezen belül is a népszámlálások kutatási célú hasznosítását, illetve az ezekhez való hozzáférhetőség kérdéseit (Harcsa 2010).

Nagy Péter Tibor e tekintetben közvetlen formában hasznosítható javaslatokat fogalmaz meg. Jó lenne, ha az általa felvetett lehetőség a jövőben nem maradna puszta kívánság, hanem mühelyközi együttmüködés keretében valóra válhatna. Az írás első része arról szól, hogy a szerző az elmélyült szociológiai elemzések számára „kezelhetővé tette" a népszámlálások egymástól különálló adatállományait, és ily módon páratlan lehetőséget nyitott az adatállományok legkülönbözőbb célú hasznosítására. Sőt, példák sorával maga hívja fel a potenciális érdeklődők figyelmét a konkrét tematikai elemzések lehetőségeire. Úgy véljük, hogy ennek különleges a jelentősége, hiszen nem szokásos gyakorlat „virtuális tutorként” segíteni azokat, akik nem járatosak a statisztikai adatbázisok kezelésében. A továbbiakban a szerző kettős céljához kapcsolódva külön-külön kitérünk a népszámlálások kutatási célú hasznosíthatóságával, illetve az iskolázottsági egyenlőtlenségek mérésével foglalkozó anyagrészekre. Mindezt vázlatos kritikai értékelésnek is lehet tekinteni.

\section{Népszámlálási adatállományok kutatási célú hasznosithatósága}

$\mathrm{A} z$ alapos módszertani elemeket tartalmazó írás, ezen belül is a benne felvetett hasznosítási javaslatok, továbbgondolásra késztettek, amelyek vázlatos formában a következők. Kívánatosnak tartjuk a szerző azon kezdeményezésének a felkarolását, amely a 2001., a 2011. évi népszámlálás, valamint a 2016. évi mikrocenzus adatállományainak kutatási célú hasznosíthatóságát szolgálja, amelyhez egyébként konkrét módszertani fogódzókat is adott. Itt említjük meg, hogy a Fényes Elek Társadalomstatisztikai Egyesület (FETE) - amelynek Nagy Péter Tibor is tagja - már a korábbi években is kezdeményezte a statisztikai adatállományok kutatási célú hasznosíthatóságát, és erről szakmai vitákat is kezdeményezett. Továbbá, a BCE Szociológia és Társadalompolitikai Intézet Társadalomstatisztikai Kutatóközpont (BCE SzTI TKK) szakmai programjában felvetette a hallgatók és doktoranduszok kutatásokba való bevonását.

2016-ban jött létre a BCE Szociológia és Társadalompolitikai Intézet Társadalomstatisztikai Kutatóközpont (BCE SzTI TKK), amelynek egyik célja „hallgatók, doktoranduszok és kutatók bevonása a kutatásokba, részben a rekrutációs bázis kialakítása, részben az oktatási tevékenység támogatása érdekében.

4 További fontos törekvésként említhető a KSH és a kutatókat képviselő Statisztikai Felhasználói Tanács (SFT) - 2014-ben megfogalmazott - „közös nyilatkozata”, amelynek 2. pontja az alábbiakat tartalmazza: „KSH biztosítja, hogy a Budapesten található kutatószobájában közvetlen azonosításra alkalmatlan mikroadatait az SFT-tagok kutatói, oktatói, PhD-hallgatói kutatói elemzések céljára használhassák. Az SFT-tagok tudomásul veszik, hogy a kutatószoba használata során az azt igénybe vevők kötelesek betartani a KSH belső - kutatószobára vonatkozó - szabályait." 
Ez utóbbi elképzelés megvalósításához szinte „módszertani segédletként” kínálkozik a szerző írása azzal, hogy - a szociológiai kutatások számára kialakított adatállományokon - konkrét témaköröket is javasol a jövőbeli kutatásokhoz. Úgy véljük, hogy a BCE SzTI TKK - a doktori iskolákkal karöltve, mühelyközi együttműködés keretében - nagyon hasznos és tartalmas precedenst tudna felmutatni a népszámlálások és mikrocenzusok kutatási és oktatási célú hasznosításával. Ehhez egy nagyobb szabású programot kellene kialakitani, amelyhez - az adatállományokat hasznosító intézmények mellett - a KSH-t is partnerként kellene bevonni.

\section{Kulcselemek a programban}

1. Már az írásról szóló vitát is oly módon kellene felvezetni, hogy ez egyúttal az érdeklödés felkeltetésére irányuljon, majd ezt követően a hallgatók, doktoranduszok, leendő doktoranduszok igényének az összegzésére, kiértékelésére kerülhetne sor. Ehhez párosulna egy felhívás, amely a műhelymunkában való részvétel feltételeit tartalmazná. Az érdeklődők jelentkezése alapján összeállítható egy 2-3 éves szakmai program, konkrét témakörökkel, és megjelölve az érintett kutatók nevét, valamint bemutatva a kutatási koncepcióikat.

2. A hallgatók, doktoranduszok mühelymunkában való részvételét célszerü lenne kreditpontokkal honorálni.

3. Feltétlenül szükség lenne egy tutori rendszer kialakitására, amelynek keretében a kutatást vállalók megfelelő szakmai támogatást kapnának.

4. A kutatásokban részt vevők lehetőséget kapnának arra, hogy az általuk elkészitett tanulmány széles körü mübelykonferencián kerüljön megvitatásra.

5. A megfelelö minöségü tanulmányokat célszerü lenne önálló kötetben publikálni, elektronikus formában való elérhetöséggel.

6. Végül a programboz bizonyos anyagi alapokat is hozzá kellene rendelni, amit OTKAvagy egyéb forrásokból lehetne biztosítani.

\section{Milyen esélye van a kezdeményezés megvalósitásának?}

Az esélyek latolgatásakor az egyik szempont az lehet, hogy milyen föbb témakörök kutatására nyújthatnak egyedülálló lehetőséget a népszámlálások, illetve a mikrocenzusok adatállományai, a másik pedig az, hogy e témakörökben - kénytelen-kelletlen - milyen „bevett” empirikus módszereket preferálnak a kutatók, föleg a mainstreamhez tartozók, amely meghatározó az újonnan pályára lépő szociológus nemzedékek szempontjából, hiszen ebben a szakmai kultúrában szocializálódnak.

A „bevettséget és kénytelenséget” mint korlátozó tényezőt különösen fontosnak tartjuk, mert - a "22-es csapdájához” hasonlóan - ez esetben is egymással szorosan kapcsolódó gyökerek kedvezőtlen kihatásáról van szó. Az egyik "gyökeret” a Statisztikai Hivatalok által végzett népszámlálásokhoz, mikrocenzusokhoz, valamint a több tízezres, tehát valóban nagymintás adatállományokhoz való kutatói hozzáférés korábbi nehézségei jelentik, amelyek - kevés kivételtől eltekintve - automatikusan a kismintás felvételek használata felé sodorta a kutatókat. A „kénytelenségből” később bevett erény lett, amely nem maradt következmények nélkül, ám erre a továbbiakban még kitérünk. 
A szerző által példaszerűen felsorolt témakörök többségéről elmondható, hogy azok többnyire - a társadalmi tagolódás és rétegződés főbb jellemzőinek a feltárásához kínálnak más forrásból nem pótolható információkat. Tömören fogalmazva a makroszociológia és ezzel összefüggésben társadalomstatisztika körébe sorolható kérdéskörök átfogó, a részleteket is kibontó bemutatásához. Ugyanakkor számos apró jelenség kutatására is olyan lehetőség van (ezekre is utal a szerző), amelyre más források alapján legfeljebb részleges információk állnak a rendelkezésre.

Egyik korábbi írásunkban (Harcsa 2015) korábban már foglalkoztunk a társadalmi tagolódás és rétegződés kutatások szociológián belüli helyzetével, különösen azzal a kérdéskörrel, hogy miért és miként kerültek az utóbbi két évtizedben háttérbe a társadalom szerkezetével és müködésével kapcsolatos „nagykérdések”, és ezzel párhuzamosan egyegy „kisebb/rész” jelenség megfigyelésének előtérbe kerülése. A jelenség okai szerteágazóak, amelyek közül - a téma kapcsán - most csupán azt a tendenciát emelnénk ki, amely a kutatások kismintás vizsgálatokra való túlzott leszúkítésére utal. A kismintás vizsgálatok társadalomkutatáson belüli korlátaira Szelényi Iván is felhívta a figyelmet (Szelényi 2016), és erre vonatkozó tapasztalatait és intelmeit célszerűnek véljük idézni.

„Legfőbb módszerünk a véletlen mintákon alapuló survey-módszer volt, amivel egészen meglepő sikereket értünk el. Ha mintánkat kellő körültekintéssel választottuk ki, viszonylag kevés (nébány száz) válaszadó megkérdezésével is előre tudtuk jelezni akár egy százmilliós népesség választási magatartását is. Ez iszonyatosan nagy teljesítmény, és borzasztó mértékben meg is növelte tudásunkat a társadalmi, politikai és a gazdasági folyamatokról. Ennek ellenére egyetlen árva centivel sem vitt bennünket közelebb az oksági hipotézisek ellenőrzéséhez." (Szelényi 2016: 121.)

Nos, ilyen - viszonylag kis mintákra alapozott - álsikerektől hemzseg a társadalomkutatás egésze, tehát nem csupán a szociológia. Tény azonban, hogy nem minden survey volt hasztalan bizonyos oksági hipotézisek ellenőrzéséhez, és itt elsősorban a több tízezres nagymintás felvételekre gondolunk, ami többnyire csak a Statisztikai Hivatalokban fordul elö. (Önmagában természetesen a nagyminta sem ad garanciát az oksági összefüggések tesztelésére.) Sajnos ezek a nagymintás társadalomstatisztikai/makroszociológiai felvételek, vagy népszámlálások és mikrocenzusok csak elvétve kapcsolódtak össze célzottabb oksági hipotézisek tesztelésére alkalmas, elmélyültebb szociológiai adatgyüjtésekkel. Úgy véljük, hogy alapvetöen csak a makro-, illetve a mikroszociológiai megközelitési módok együttes alkalmazása révén lebet igazán nagy ívü kutatási koncepciókat megvalósítani.

A „kénytelenség és a bevettség” még ma is „nagyúr”, amelyre egyik példaként említhetjük az MTA Szociológia Kutató Intézetének 2016-ban „Társadalmi integráció és rétegződés" témában végzett vizsgálatát, amelynek mintanagysága 3000 fő körüli volt, és ami a szociológiai mainstreamben már viszonylag nagymintának számít. Vitathatatlan, hogy bizonyos kérdések megválaszolására ekkora minta is elégséges, azonban a kérdéskörrel kapcsolatos, számos alapvető társadalmi folyamat hatásának a bemutatásánál komoly korlátok jelentkeznek, sőt adott esetben fennáll a félreértelmezés veszélye (Harcsa 2017).

Egy ilyen szakmai miliőben fennáll annak a veszélye, hogy a témakörben érintett vezető kutatók sem igazán értik az itt felvetett kezdeményezést, hiszen akár az oktatás (itt elsősorban a szociológiai doktori iskolákra gondolunk), akár a kutatás terén - a kényszerek és lehetőségek hatására - meghatározott gondolkodásmódok, és ezzel kap- 
csolatos protokollok alakultak ki, ami egyfajta „tudásgyári” müködésre utal. Bizonyos mértékig ezt támasztja alá az előzetes tájékozódás keretében nyert tapasztalatunk is. Ezzel kapcsolatosan csak emlékeztetni szeretnénk a kezdeményezés - itt megfogalmazott - első elemére, amely a következő volt: „Már az irásról szóló vitát is oly módon kellene felvezetni, hogy ez egyúttal az érdeklödés felkeltésére irányuljon, majd ezt követően a hallgatók, doktoranduszok, leendő doktoranduszok igényének az összegzésére, kiértékelésére kerülhetne sor." Nos, a vita előkészítése során két fővárosi szociológia doktori iskolát is megkerestünk abból a célból, hogy képviselőik fejtsék ki az álláspontjukat a felvetés kapcsán. Az egyik helyről azt a választ kaptuk, hogy az illető „nem látja, hogy milyen szerepe lehetne a kezdeményezéssel kapcsolatos vitában”. Ugyanakkor felajánlotta, ha a szerző (Nagy Péter Tibor) konkrét témakörök kutatására tesz javaslatot, akkor azt kirakják a doktori iskola megfelelő hirdetési blokkjába. Az illető egyértelművé tette, hogy a „nem hagyományos” kutatási módszer, illetve ezzel kapcsolatos kezdeményezés nem fér bele a kialakult protokollba. Úgy véljük, hogy e példa is a szakmai viszonyok rugalmatlanságára utal.

\section{Az iskolázottsági egyenlőtlenségek mérése}

Úgy vélem, hogy az idöszaki, beleértve a legutóbbi idöszakra vonatkozó trendek bemutatása bizonyos fokig korlátozott, ha nem ágyazzuk be a társadalomtörténeti elözményekbe, tehát ha nem vázoljuk fel a „honnan hová” vezető út föbb jellemzőit. Hasznos lett volna tehát, ha a szerző egy hosszabb időszak keretein belül értelmezte volna a 2011-2016 közötti időszak változásait.

Ennek bizonyos fokig a szerző is tudatában van, mert leszögezi: „A 2011-es és 2016os iskolázottság közötti távolság persze csak csekély mértékben engedi meg következtetések levonását a 2011 és 2016 közötti oktatásügyi folyamatokra nézve." (NAGY 2017: 542.) E megállapításához csupán azt szeretnénk hozzáfüzni, hogy időbeli viszonyítási alapok nélküli értékelés ily módon „féloldalas”, ám a nagyobb baj az, hogy később a szöveg önálló életet él, és ezek a korlátok már feloldódnak az olvasó tudatában, következésképpen értelmezési zavarokhoz vezethet. A szerző ugyan megemlíti, hogy az Educatio következő számában majd a 2001. évi adatokat is bemutatják, azonban szerencsésebb lett volna, ha ezek az idősorok egy helyen, egymásra vetítve kerültek volna bemutatásra és értékelésre.

A szerző e problémát - igen jó megoldásként - a kohorsz elemzés révén próbálja mérsékelni, oly módon, hogy „személysoros” formában kezeli a rendelkezésre álló adatokat. Ennek megfelelően a 2011-es adatállományból „kivág” egy-egy kohorszot, megnézi iskolázottsági adatait, majd összehasonlítja ugyanezen korcsoportok 2016. évi adataival, és értelmezi az elmozdulásokat. A választott módszert a szerző kutatási célja határozza meg, amelyet az alábbiakban foglalt össze:

„Most azt kívánjuk bemutatni, hogy ellentétben a sokféleképpen értelmezhető és mindenekelőtt a tanügyigazgatásnak alávetett iskolai adatszolgáltatással a lakossági adatszolgáltatáson alapuló iskolázottsági egyenlőtlenségek változása még két, viszonylag közeli időpont esetén is érdemben tükrözi az adott időszak folyamatait. A 2011-es és 2016-os állapotot azért hasonlítjuk össze, hogy ebbe a kettős kormányzati ciklusba eső 5 esztendő munkaerő-politikájának, társadalompolitikájának, oktatáspolitikájának, fejlesztés politikájának hatását mérjük." (I. m. 544.) 
A szerző szándéka kapcsán kérdésként fogalmazzuk meg, hogy vajon lehet-e kellő alapossággal értelmezni egy adott időszakot (jelen esetben a 2011-2016. közöttit) az előző időszak érdemi kritikai értékelése nélkül? Tömör válaszunk az, hogy nagyon erős korlátok között. Miért? Elsősorban azért, mert számos társadalmi jelenség - így az oktatási folyamat is - „útfüggo””, ami azt jelenti, hogy az egyes korszakok magukkal cipelik a korábbi időszak „hordalékait”, következésképpen célszerü kísérletet tenni az örökölt helyzet kezelésével kapcsolatos lépések elkülönitésére az új korszak „önjáró” kezdeményezéseitől. A tisztánlátás érdekében mindkettő külön-külön kritikai értékelést érdemel.

\section{Megjegyzések a szerzö következtetéseihez}

A szerző sok munkával viszonylag kevés következtetést tudott levonni az iskolázottsági egyenlőtlenségek 2011-2016 közötti alakulására vonatkozóan, ám feltételezem, hogy a kutatás jelenlegi fázisában nem is ez volt a célja. Úgy vélem, hogy a jelenlegi következtetések még nem igazán relevánsak „a kettős kormányzati ciklusba eső 5 esztendő munkaerö-politikájának, társadalompolitikájának, oktatáspolitikájának, fejlesztéspolitikájának, illetve ezek hatásának mérésére".

Maradjunk azonban most csupán az oktatáspolitikai hatások megjelenítésénél, amellyel kapcsolatosan a szerző az alábbi megállapítást teszi: „Mégis ezekből az adatokból az tükrözödik, hogy az öt év folyamatai azt eredményezték, hogy a szülö iskolázottsági és területi hátrányok ezekben az alsó évfolyamokban növekedtek.” (I. m. 554.)

A szerző öt pontban foglalja össze az általa vélt hátrányok újratermelődését. Ezek közül valójában csak három esetében lehet kedvezőtlen tendenciákat megfigyelni. E három esetében is alapvetően a társadalmi tagolódásban bekövetkezett strukturális hatások (beleértve a demográfiai jellegüeket) jelennek meg, és kevésbé az oktatáspolitikáé, amit a konkrét állításokhoz füzött kommentekben jelzünk.

a) "A csecsemök szüleinek iskolai végzettsége 2011 óta érzékelhetően lefelé tolódott el." E megállapítást a tények nem támasztják alá, az árnyalt helyzetet pedig csak többféle megközelítés együttes figyelembevételével lehet felvázolni. Egyrészt már a 2000-es évek eleje óta megfigyelhető, hogy a születések számának a növekedése csak az alacsonyabb iskolai végzettségü csoportokban figyelhető meg (Harcsa-Monostori 2018). Ez önmagában azt eredményezi, hogy a csecsemők körében növekszik az alacsony iskolai végzettségü anyák hányada. (Feltehető az is, hogy közöttük növekvő hányadot képviselnek a roma családok.)

Tény ugyanakkor, hogy ha az élveszületéseket az anya iskolai végzettsége szerint nézzük, akkor 2011 és 2016 között nem történt érdemi változás. Kérdés, hogy miért, hiszen az alacsony végzettségü anyák részaránya - az iskolarendszer folyamatos kiterjesztése következtében - a gyermekes családokon belül fokozatosan csökken, és ezzel párhuzamosan növekszik a felsőfokú végzettséggel rendelkező anyáké. A strukturális változás önmagában „lefelé nyomja” a gyermeket szülő, alacsony státusú anyák hányadát. A magyarázatot az adja meg, hogy - mint említettük - a legfeljebb 8 általánossal rendelkezők körében folyamatosan növekszik az átlagos gyermekszám, amely kompenzálni tudja a strukturális hatások által gerjesztett deficitet. 
További torzítást okozhat az a körülmény is, hogy egyre növekszik a külföldön született, tehát a kivándorló szülőktől származó gyerekek száma, akik zömében a középrétegekhez tartoznak. Ök értelemszerüen nem jelennek meg a népszámlálási adatokban.

Azt lehet tehát mondani, hogy a 2000-es évek eleje óta született gyermekek szüleinek az iskolai végzettségét nem a 2011 és 2016 közötti oktatási folyamatok határozták meg. A szerzö által érzékelt jelenség alapvetöen demográfiai következmény, amelybez nincs köze az oktatáspolitikának.

1. táblázat: Élveszületések az anya iskolai végzettsége szerint (\%)

\begin{tabular}{lccc}
\hline & 2001 & 2011 & 2016 \\
\hline Általános iskola & 28 & 20 & 21 \\
Szakmunkás, szakiskola & 24 & 14 & 12 \\
Érettségi & 32 & 31 & 32 \\
Felsőfok & 16 & 34 & 33 \\
Ismeretlen & 0 & 1 & 2 \\
\hline Összesen & 100 & 100 & 100 \\
\hline
\end{tabular}

(Forrás: Demográfiai Évkönyvek)

2. táblázat: Gyermekes családok az anya iskolai végezettsége szerint (\%)

\begin{tabular}{lccc}
\hline Az anya iskolai végzettsége & 2001 & 2011 & 2016 \\
\hline Általános iskola & 18,5 & 13,0 & 10,7 \\
Szakmunkás, szakiskola & 27,2 & 24,8 & 20,9 \\
Érettségi & 34,5 & 34,6 & 35,0 \\
Felsőfok & 19,8 & 27,6 & 33,4 \\
\hline Összesen & 100,0 & 100,0 & 100,0 \\
\hline
\end{tabular}

(Forrás: népszámlások és a 2016. évi mikrocenzus, saját számítás alapján)

b) „Az általános iskolai elörehaladásnál a nyolc osztálynál kevesebbet végzett szülők gyermekei az átlaghoz képest 2011-ben 3,6-szeres hátrányban vannak, ez a hátrány 2016-ra 4,3-szeresre nö. A nyolc osztályt végzett családfök gyerekeinek a hátránya változatlan marad, az ennél iskolázottabbaké javul kissé."

Itt valójában az underclass ${ }^{5}$ helyzetének a további romlását lehet megfigyelni, nevezetesen egyre szükül a 8 osztályt el nem végzők köre, amely azt is jelenti, hogy e rétegekben egyre töményebben jelenik meg a szegénység és a társadalmi leszakadás. Ezt is egy rövid távon visszafordíthatatlan strukturális hatásnak tekinthetjük. Természetesen ez nem ad felmentést az aktuális kormányzatnak arra, hogy a jelenséget figyelmen kívül hagyja.

5 A fogalmat Szelényi Iván honosította meg a hazai szociológiában. 
c) "Az általános iskolai elörehaladásnál a hátrányos belyzetü települések lakosai 2016-ban 1,1-szer nagyobb hátrányban vannak, mint 2011-ben."

$\mathrm{A} z$ említett underclasshoz tartozók egyre növekvő hányada éppen a hátrányos helyzetü településeken tömörül, tehát itt is alapvetően strukturális hatásról van szó, hiszen az általános iskola 4-5. osztályába járó gyerekek szüleinek az iskolai végzettségét nem az utóbbi évek oktatáspolitikája határozta meg.

Itt érdemes megemlíteni azokat a kutatásokat, amelyek a nemzedéki újratermelődés anomáliáinak a vizsgálata során éppen a hátrányos helyzetű kistérségekben mutatták ki a végzetes, peremre sodródás folyamatát és következményeit (Gazsó-Laki-Pitti 2008). Arra a megállapításra jutottak, hogy - az adott viszonyok között - szinte törvényszerüen alakulnak ki az egymásra halmozódó, kedvezőtlen strukturális folyamatok.

Alapvető gond tehát, hogy az írás nem ad kellő empirikus bizonyítékot arra vonatkozóan, hogy a szerző által mért romlási tendenciákban mekkora szerepet játszottak a múltban gyökerező, és azóta önjáróvá váló folyamatok, és mekkorát az utóbbi néhány év oktatáspolitikája. A sokdimenziós társadalmi térben formálódó, tartósan kedvezőtlen folyamatok ugyanis hosszabb távon képesek megalapozni a „rossz körök” újratermelődését. Következésképpen ezek hatása jóval nagyobb annál, mintsem egyetlen alrendszer, jelen esetben az oktatási rendszer ezen érdemben tudna segíteni. A bajok gyökerei sokfelé vezetnek, ezért azok kezelése is csak sok irányból vezethet kellő eredményre. A rendszerből egyetlen elem legfeljebb időlegesen tud „kilógni”, azaz csak rövid időre tudja relatíve függetleníteni magát a teljes rendszertől.

Miután a szerző a 2001. évi népszámlálási adatainak feldolgozásával folytatja a kutatást, ezért a közeljövőben összeáll az idősor, amely alapján valóban releváns következtetéseket lehet majd levonni az iskolai egyenlőtlenségek alakulására vonatkozóan, továbbá arra vonatkozóan is, hogy a - hosszabb távon - folyamatosan újratermelődő egyenlőtlenségek alakulásához milyen mértékben járult hozzá a jelenlegi politikai kurzus 2011-2016 között folytatott iskolapolitikája. A reménybeli új eredményeket a közlés előtt célszerü lenne szélesebb szakmai körben megvitatni, már csak azért is, mert a közvetlen formában megjelenő kölcsönös visszajelzéseknek komoly megtermékenyítő hatásuk lehet.

\section{IRODALOM}

Gazsó F., Laki L. \& Pitti Z. (2008) Társadalmi zárványok. Budapest, MTA Politikai Tudományok Intézete.

HarCSA I. (2010) Műhelykonferencia az adminisztratív adatállományok statisztikai célú hasznosításáról - különös tekintettel a népszámlálásra. Statisztikai Szemle, Vol. 88. No. 5. pp. 550-552.

Harcsa I. (2015) Úton „egy kellően komplex és átgondolt, empirikusan is megalapozott társadalomkép felé”. Gondolatok Éber Márk: Megkülönböztetett különbségek című müvének főbb következtetései kapcsán. Replika, Vol. 25. No. 92-93. pp. 231-245.

Harcsa I. (2018) Gondolatok az adminisztratív adatforrások statisztikai célú hasznosíthatóságáról. Kézirat. 
Harcsa I. \& Monostori J. (2018) A háztartásszerkezet és az iskolai végzettség összefüggései. In: Kolosi T. \& Tóth, I. Gy. (szerk.) Társadalmi Riport 2018. Budapest: TÁRKI, pp. 109-124.

NaGy P. T. (2017) Az iskolázottsági egyenlőtlenségek és a 18 év alatti népesség a 20112016-os időszakban. Educatio, Vol. 26. No. 4. pp. 540-556.

SzElÉnyi I. (2016) A szociológia hármas válsága. szocio.bu, Vol. 6. No. 1. pp. 118-126. Interneten: http://socio.hu/uploads/files/2016_1/szelenyi.pdf.

A cikk a Creative Commons Attribution 4.0 International License (https://creativecommons.org/licenses/ by/4.0/) feltételei szerint publikált Open Access közlemény, melynek szellemében a cikk bármilyen médiumban szabadon felhasználható, megosztható és újraközölhető, feltéve, hogy az eredeti szerző és a közlés helye, illetve a CC License linkje és az esetlegesen végrehajtott módosítások feltüntetésre kerülnek. (SID_1) 